a source of information relating to the industries of neolithic man, Grime's Graves is without rival ; while the circle of Arbor Low in Derbyshire, and the megalithic barrows of the Cotswolds each hold a place in British prehistory, of which the importance needs no emphasis. It may be noted, however, that the latter are counted the oldest monuments under the guardianship of the Office of Works. Verulamium, since Dr. Mortimer Wheeler's excavations, is unique both as a British and a Romano-British site. In historic periods the abbeys of Shropshire and the castles, such as Framlingham, stand out among medieval buildings; while Kirby Hall, Northants, is one of the most important of the large country houses of Elizabethan and Jacobean times. For the first time, historic buildings belonging to the Crown appear. These are the Tower, Hampton Court, Kensington Palace, and the Chapter House of Westminster. Of the various periods into which English prehistory and history fall, the Saxon alone does not appear among the historic monuments under protection.

\section{Ethnology of the Far East}

THE authorities of the Raffles Museum, Singapore, have added a new series, to be known as Series B, to the Museum Bulletin. The present publication, which will now become Series A, hitherto has been devoted almost entirely to communications of a biological character. The new series will be anthropological, and for some time to come will be devoted largely to publication of the results of a scheme of research in the prehistory of the Malay Peninsula, for which the Carnegie Corporation of New York has voted a subvention extending over a period of three years. In the first issue of the new series are three reports on recent excavations-the first in Kedah by Mr. H. D. Collings, the second in a cave in Bukit Christamani by Mr. M. F. W. Tweedie, and the third on kitchen middens at Guak Kepeh, Wellesley Province, by Dr. P. V. van Stein Callenfels. The most important, as well as the longest, communication is from Dr. van Stein Callenfels, who, in "The Melanesian Civilization of Eastern Asia", contributes a detailed analysis of the Hoabinian stone age culture, so called from the early culture first distinguished in Tonkin, which he traces throughout the East so far as observed from China and Japan to Celebes, and analyses into three stages, in which he sees evidence for contacts between a people of a palæolithic type of culture with another in a protoneolithic stage. In incorporating the new evidence obtained under the present scheme in his analysis, and at the same time making use of the evidence afforded by earlier excavations in the Malay Peninsula, notwithstanding their defects in method, Dr. van Stein Callenfels also turns to the discussion of the position of Wadjak man, to whom he is inclined to assign a date later than the Pleistocene, but to regard him as a very old representative of the Melanesoid culture.

\section{The Consumption of Statistics}

Is his inaugural address on November 18 as president of the Royal Statistical Society, Lord Kennet urged the necessity for a more effective consumption of statisties. He affirmed that statisticsin the broad sense of the collection and methodical arrangement of facts-provide the one indispensable food from which the organs of Government can derive the motive power for the right conduct of the business of governing the nation. Decisions made without adequate statistical study on questions of the magnitude and complexity with which modern Governments have to deal, are not in the least likely to be even approximately correct, and the resulting policies and measures would be little better than the medicine-man's sympathetic magic carried out by incantation. Without doubt, then, the Government ought to be the most substantial consumers of statistics. If the Government consumes statisticsand it undoubtedly does to some extent both consume and digest them-the results of Government action seem to show that the metabolism is defective. What part of the organism is at fault? Lord Kennet classified the effective organs of Government as the Press, the wireless, the Civil Service, the Cabinet, the House of Commons, the voters at election time, the local authorities. Which of these is to blame? The fault must be directly attributed to the executive government, but the blame lies fundamentally with their masters, the people, whose national predilection is for 'muddling through', and who believe that scientific study has little practical value. Theory and practice are in reality not opposed but complementary to one another, and the widespread belief to the contrary is responsible for much of the mental lethargy which makes our conduct of affairs what it is-too often a fortuitous muddle.

\section{Coal Gas Research}

Ar the eighth Autumn Research Meeting of the Institution of Gas Engineers held in London on November 3-4, the papers showed current trends of thought in the gas industries. The thirty-ninth report of the Joint Research Committee of the Institution and the University of Leeds gave the first instalment of a study of the complete gasification of coal in oxygen-steam mixtures. Such a process, if successful, might make the industry less dependent on the choice of coal, and less would be required. At the same time it would have far-reaching consequences on the distributions of fuel. This report contained a study of the conditions within a fuel bed during gasification. Three papers dealt with the sulphur impurity in coal gas. Coal gas is the purest fuel in general use, but this very purity renders possible its use in flueless apparatus, and the small quantity of sulphur compounds present may become noticeable even if innocuous. The paper shows that the coal gas of the future may be purified of sulphur compounds to a degree hitherto unknown. The paper by H. Hollings on the formation and removal of gum in coal gas reveals the solution of a baffling problem which has arisen following the use of the practice of drying gas before distribution. Traces of unsaturated hydrocarbonsalmost inconceivably minute-condense or polymerize to form gummy substances which may cause trouble in appliances. The solution of this puzzle is 
a marked achievement of industrial chemical research. A. R. Bennett and H. Hartley described an instrument for measuring the radiation from heating appliances, which should be serviceable for other uses.

\section{Air-Conditioned Flats}

Eaton House, Upper Grosvenor Street, London, W.I, has been converted into a building containing thirty luxury flats. They are equipped for electric cooking and refrigeration, and hot water is supplied from a central hot water plant in the basement. We learn from the Electrician of November 6 that each tenant has an air-conditioning plant completely under his own control. Both the temperature and humidity of the air can be adjusted by the tenant to any value he pleases. In each flat there is a condensing unit working in conjunction with an airconditioner, consisting of a slow-speed fan and motor, heating coils, cooling and dehumidifying coils, air filter and humidifying spray for winter use. The airconditioners are housed in cupboards in the kitchens of each flat and cleverly concealed. Each conditioner passes approximately $1,300 \mathrm{cub}$. $\mathrm{ft}$. of air per minute. About twelve complete changes of air per hour are provided in the rooms. It is essential that the plants be practically inaudible as they are in operation twenty-four hours a day. This has been effected by mounting the units in pedestal anti-vibrators. The filtered fresh air enters through grilles in the walls, and as there is no need to open windows street noises, grime and dust can be kept out. A small wall panel in the hall of each flat carries the temperature and humidity control apparatus. It consists of a thermostat, humidistat and change-over rotary switch. An advantage of individual control is that if a flat be left empty, the entire plant can be switched off and thus save running costs. The equipment was designed and installed by York, Shipley, Ltd. of North Circular Road, London, N.W.2. For the electricity the tenants pay a small quarterly fixed charge and $\frac{1}{2} d$. per unit.

\section{Testing Switchgear}

THE safety of every electricity supply system depends on its switchgear always being ready to operate. The main switches (circuit-breakers) must always be capable of making and breaking the current, and still remain fit for use. The development of the grid system has proved the necessity of being able to 'clear' a fault even when fed by enormous currents. For many years, the firms now constituting Associated Electrical Industries have had extensive experience of short-circuit tests made with generators having capacities up to 80,000 kilovolt amperes. In an article in Electrical Industries of October 14, a description is given of a testing station having a generator capable of giving $2,500,000 \mathrm{k} . \mathrm{v} . \mathrm{a}$. on short circuit. In order to meet the demand for more tests and for tests at higher powers, the companies interested combined to form a separate company known as the Switchgear Testing Co., Ltd., which now owns and operates the plant on their behalf. The testing station is situated at Trafford Park,
Manchester. Ample space had to be provided to ensure personal safety, and, when 'testing to destruction', to avoid damage to property by explosion and fire. The station has three testing areas; two are covered over and used for testing up to $33 \mathrm{kv}$, and one is an open area, testing up to the grid voltage of $132 \mathrm{kv}$. The station has a complete equipment for measuring and recording phenomena. Its electromagnetic oscillograph has sixteen elements and is probably the only oscillograph of this kind in the world. It is satisfactory to know that these companies have taken a leading part in conjunction with other firms both in Great Britain and abroad in producing a standard specification for procedure in testing circuit breakers which is recognized internationally.

\section{Marine Work in Ceylon}

THE Administration Report of the Marine Biologist, Mr. A. H. Malpas, for 1935 (Part IV-Education, Science and Art (G), Marine Biology : published May 1936) shows that the inspection of the pearl banks again reveals an absence of sufficient spatfalls of both southern and northern paars to provide fisheries within the next three years, despite the presence of sexually mature oysters in sufficient quantity to repopulate the banks. Although conditions of the kind have always been attributed to adverse currents carrying away the free-swimming larvæ into deep water where they are lost, there seems to be some justification for the belief that hydrobiological conditions in the Gulf of Manaar are the more important factors in so far that adult pearl oysters can be stimulated to maximum spawning only under particular conditions of salinity and temperature, which are the exception, rather than the rule, and therefore the pelagie larvæ are not developed in sufficient numbers to produce spatfalls except when these conditions obtain. The scheme referred to in last year's report for the establishment of a Fisheries Research Station at Colombo combined with an aquarium has been modified, and the suggested aquarium available for the public abandoned, a more comprehensive scheme with experimental aquaria and provision for a fish hatchery on a fairly large scale being substituted. This will provide not only for facilities for investigating the bionomics of marine and freshwater animals of economic importance but also for experiments in hatching and rearing the more important freshwater food fishes.

\section{The London School of Hygiene and Tropical Medicine}

A REPORT by Sir Austen Chamberlain, chairman of the Court of Governors, giving a short account in non-technical terms of the work of the London School of Hygiene and Tropical Medicine (incorporating the Ross Institute) for the information of those who contribute to its maintenance, has been issued to subscribers. Commencing with a short history of the establishment of the London Tropical School in the hospital of the Seamen's Hospital Society at the Royal Albert Dock, its removal to Endsleigh Gardens, and finally its incorporation in the London 